\title{
Textile Innovations Delivery of Extension Services Programme for Rural Economic Empowerment and Development in Nigeria
}

\author{
K.O. Ajila \\ Department of Family, \\ Nutrition \& Consumer Sciences, \\ Faculty of Agriculture, \\ Obafemi Awolowo University, \\ Ile - Ife, Nigeria
}

DOI: https://doi.org/10.36941/mjss-2021-0026

Abstract

The study assessed textile innovations delivery of extension services programme in Nigeria, with a view to establishing its proficiency for rural economic empowerment and development. Explicitly, it examined the project techno-dynamics factor; analysed its economic costume and visibility variables. For this study 10 states and 40 blocks were purposively selected and 320 groups of villages within the selected blocks were visited. Stratified and simple random sampling procedure was used in selecting $15 \%$ of respondents from each group of villages, making 3,251 across the nation. While structured and pre-tested questionnaire was used in collecting quantitative data, individual interview schedule and Focus Group Discussions (FGDs) were applied in eliciting qualitative information from respondents. Data collected was summarized with the use of descriptive statistics viz; percentages, means and, frequency counts. Factor analysis was applied in isolating critical factors having relationship with proefficiency. The study isolated three important factors that were crucial to proficiency. These were textile innovations socio- technical (25.09\%), accessibility (23.74\%) and socio-economic (20.25\%). It was concluded that the introduced textile innovations was proficient for rural economic empowerment and development. For proficiency, the finding suggests that inputs must be made available at the various extension centers, and on-farm textile producers must have direct access to market board without interference of product-coordinators.

Keywords: Textile-innovation, extension-delivery, proficiency, rural, development.

\section{Introduction}

The massive escalation in the global technology that led to drastic change in the textile sector , has contributed to dynamics of social changes in every society with sustainable economy growth worldwide. Extension organization in its wide range of structures and multiplicity of functions (Ajila 2011), has played vital roles in the episode. The fundamental heritage of extension was on concept of providing service and education to economically, socially, and culturally help each individual, family and community in achieving the highest level of sustainable living by means of self-abetted(Kolawole and Torimiro, 2005). The adopted training strategy in extension organization is by communicating relevant technologies Oluwatoyin and Adeniji (2011) concerning "on" and "non" farm activities 
through any appropriate channel to the target audience.

Originally, cotton was among the major exported cash crops in Nigeria Adeniji (2011) before the discovery of petroleum ore in 1970. Early approach to achieve national development through textile technology extension delivery by governments involves:

- $\quad$ creating productive and small-scale employment in textile,

- increase domestic supply of fibers, leather and latex to feed local industries, and keep pace with rising demand for its products and,

- $\quad$ expand textile exports for ensuring increase in national economic (Alao, Agboola, and Olaniyan, 1997; NEEDS, 2015).

To achieve these goals simultaneously along with other agricultural products and in a timely manner, government tried to strengthen textile extension services delivery for fibre production and processing Alam et al(2013), to the extent of organizing standard market board for natural fibre production. In 1977, the Integrated Rural Development Programme was established to:

- $\quad$ settle school leavers in farm settlements,

- provide school uniform scheme through system of cooperative tailoring societies,

- establish spinning mill and,

- $\quad$ rural broadloom weaving programme (Ajila and Farinde, 2012; NAERLS, 2008).

After 1979, several other rural development programmes were created such as the macro and micro economic policies of the 8o's, the fifteen - month economic emergency plan of 1985 , the Structural Adjustment Programme (SAP) of 1986 which entrenched more improved packages for textile development. Other developmental outreach in Nigeria like Better

Life Programme (1987), Family Support Programme (1994), Poverty Alleviation Programme (2000), Small and Medium Scale Enterprises Development (2007), Women-In- Agriculture Programme (WIA), and those introduced by international agencies like United Nations Development Programme (UNDP), United Nations International Children Education Fund (UNICEF) among others also instill textile innovations. In the early 200o's, the World Bank withdrew its supports for rural and agricultural development extension services in Nigeria Opler (2015), but the Government keeps on creating and funding programmes targeting rural economic developments such as Small and Medium Enterprises Development Agency (SMEDA), National Economic Empowerment and Development Strategies (NEEDS), Community Based Agricultural and Rural Development Programme (CBARDP) among others. All these ingrained textile innovation packages(Ajila and farinde,2015). Iwuchukwu, and Igbokwe (2012) recorded government efforts in resuscitating leather and skin work, cotton and, latex/rubber production and processing among others as a means of achieving economic development and sustainability in 2000. In 2005, Federal Government of Nigeria placed embargo on importation of textile goods for the development and adoption of indigenous textile products. Again in 2009, he launched Cotton, Textiles and Garment industry revival (CTG) scheme which was targeted at micro and macro-economic empowerment and development(Adeolu,2016). To be more pragmatic, in 2012, the federal government released seventy million naira ( $\left.\mathrm{N}_{70}, 000,000.00\right)$ as loan to be made available through the Bank of Industries (BOI) to textile sector. Again, provision for credit on micro and macro economic development was made available through the Bank of Agriculture (BOA) and Bank of Industries to rural and urban entrepreneurism (Odewumi \& Okunade, 2016). In 2016, most of the local textile industries that have become moribund were revived; there is bolster for embargo on importation of textile goods and, foreign investors are encouraged into the country by the federal government (NEEDS,2015).

Despite all these efforts by every government's succession, most Nigerian lived in abject poverty. Although, the nation is at the transitional juncture in the sociological developmental continuum and, the prime display crisis at this phase is poverty(Ogbimi, 2006). Ayinde (2012) in support of the Nigeria National Population Census of 2009 highlighted about 69.0 percent of Nigerian as living in the rural area and, not less than 64.0 percent of this population were youths. For certainty in the present intense of clamoring for holistic nationalism and poverty alleviation, this area 
necessitates economic empowerment for sustainability. Proficiency in achieving such goal has a need for realistic and appropriate technologies with human face. These technologies must be economically possible and supportive, culturally compatible and ecologically sound. Most importantly, it must be a technology that will retain and build upon local skill and resources(Oye, 2019), and closely reflect local wishes and needs. Any technology exhibiting aforementioned characters is of "good fit" and refers to as an intermediate. So, any project whether traditional, adapted or imported which fits best with the lifestyle of its beneficiaries, taking into consideration the environmental economic culture Ndagara (2005) and physical factors would be proficient. In that case, proficient technologies must offer solution to most pressing and worst problems of its beneficiaries but, must consider sociocultural, socio-political and economics of such environment.

Holistically, textile technology is fast growing worldwide however, progression of growth at each production segments differ between nations. Potentials at each segment can effectively and efficiently contribute to dynamics of sustainable economic empowerment and development. For rural economic empowerment, this to a large extent will depend on how extension agency integrates textile technologies into an overall strategy of its education.

\section{Objective of the study}

The main objective was to assess the proficiency of textile innovations delivery of extension programme for economic empowerment and development in Nigeria. The specific objectives were to:

i. examine textile techno-dynamics factors influencing its proficiency for economic empowerment and development in Nigeria;

ii. analyse economic costume and, visibility variables of textile innovations delivery of extension programme influencing its proficiency for economic empowerment and development in Nigeria.

\section{Methodology}

\subsection{Study area, sample selection and data collection.}

The study was conducted in Nigeria among textilis that is, men and women who used textile innovations delivery of the extension programme. The nation was divided into five agro-ecological zones (southeast, southwest, central, northwest, and northeast). Each agro-ecological zone comprises an average of seven States, with Agricultural Development Programme (ADP) office situated in each of the States. ADP in each state is organized into four levels for ease of operation viz as headquarter, zone, block and circle/cell. A State is further divided into two or three zones based on the land mass and population density. A zone is made of six to eight blocks, each block has six to eight cells/circles and each cell was splitted into nine or ten groups of village. Each group of villages has not less than five hundred textilis. In addition to the activities of ADP of Ministry of Agriculture, there are about twelve federal universities with agricultural technology transfer mechanism in Nigeria. From each of the five agro-ecological zones, two States were selected. Four blocks from each visited States; four cells from each block and two groups of villages with distinct textile activities were purposively selected as shown in Table 1. Data was collected between October- April, 2019. Stratified and simple random sampling techniques were employed in selecting 15 percent of TES beneficiaries in each group of villages, making a total of 3,251 across the nation and, 3,200 respondents who responses were coherent was analysed for the study.

Personal observation and, 138 Focus Group Discussion (FGD) sessions were held in eliciting direct information from the respondents. Ninety two sessions of the FGDs were held during the professional group meetings at village levels and, forty six at the Local Government Areas (LGAs) office. This was done in support of Academic Staff Union of Universities, in each of the visited zone.

The instruments were exposed to test - retest method for reliability at an interval of four weeks 
in Rivers, Edo, Plateau, Kebbi and Yobe States. These States are outside the coverage of the study. Spearman's rank order of correlation coefficient $(r)$ was used to compare the scores of the two surveys. An " $r$ " value of 0.74 was obtained and, adjudged as adequate.

Table 1: Showing selected Agro-ecological Zones, States and, Blocks

\begin{tabular}{|c|c|c|}
\hline Agro-ecological zones & States & Blocks \\
\hline Southeast & $\begin{array}{l}\text { i. Abia } \\
\text { ii. Anambra }\end{array}$ & $\begin{array}{l}\text { Isala Ngwa North, Arochukwu, Umuahia South and, Ugwa. } \\
\text { Anocha, Dunukofia, Onitsha North and, Onumbe South. }\end{array}$ \\
\hline Southwest & $\begin{array}{l}\text { i. Delta } \\
\text { ii. Ogun }\end{array}$ & $\begin{array}{l}\text { Aniocha, Isoko East, Okpe and, Ukwani. } \\
\text { Abeokuta South, Ijebu Ode, Obafemi Owode and, Odogbolu. }\end{array}$ \\
\hline Central & $\begin{array}{l}\text { i. Kogi } \\
\text { ii. Benue }\end{array}$ & $\begin{array}{l}\text { Advi, Okene, Lokoja and, Yagba East. } \\
\text { Buruku, Katsina- ala, Markurdi and,Ukum. }\end{array}$ \\
\hline Northwest & $\begin{array}{l}\text { i. Katsina } \\
\text { ii. Kano }\end{array}$ & $\begin{array}{l}\text { Funtua, Katsina, Malumfashi and, Charanchi. } \\
\text { Faggae, Dala, Kura and, Ungogo. }\end{array}$ \\
\hline Northeast & $\begin{array}{l}\text { i. Jigawa } \\
\text { ii. Gombe }\end{array}$ & $\begin{array}{l}\text { Birni kudu, Gwaram, Kiyawa and,Taura. } \\
\text { Akko, Funakaye, Yamaitu and, Kwami }\end{array}$ \\
\hline
\end{tabular}

Source: Field survey, 2019

\subsection{Data analysis.}

Descriptive statistical techniques were used to describe and summarize the data. Each variable of TES techno-dynamics factor was subjected to six statements of opinion of the respondents, on five point Likert scales: Strongly Agreed $(S A=5)$; Agreed $(A=4)$; Undecided $(U=3)$; Disagreed $(D=2)$ and, Strongly Disagreed $(S D=1)$. Each variable index was the summation of all scores on statements of opinion relating to such variable and, the maximum score for each was 30 and minimum was five. Again, elements of the following indicators viz are; project compatibility, skills and inputs required, income and attracted benefits was assigned one point, and total score for each respondent was calculated as proficiency index. Individual respondent's maximum scores were 32, while the minimum was zero. The responses were later categorized into three level of proficiency, using the respondents' proficiency mean score and standard deviation viz: High level = mean score + standard deviation; Low level = mean score - standard deviation; while Average level = scores less than high level but higher than low level of proficiency. Factor analysis was used in isolating and grouping variables that were crucial to proficiency of textile innovation delivery.

\section{Results and Discussion}

\subsection{Textile techno-dynamics factor: Selected variables viewed under this factor include:}

\subsubsection{Relative advantages}

Relative advantages (R.A) of textile innovations were analyzed to identify its superiority over existing ones in the study area. Ninety five percent of the respondents were convinced that packages of TES introduced were relatively superior to existing textile technologies in the studied area. Reason was in accordance with Onjeiwo (19197) that there was an apparent increase in respondent's economic outputs, with short time - output ratio. This finding specified introduced innovations as time effective. While 97.0 percent strongly agreed that creative and technical skills gained through introduced project were far better than the existing skills, one hundred percent of the respondents said, there were lots of other benefits embedded in the innovation. Ninety three percent identified their participation to have enhanced them good management and networking skills, which is the ability to connect with a broad range of contact in the field of business for the purpose of sharing vested information mostly on economic purpose. This singular skill has improved marketing 
strategies with increase in patronage and contacting customer with ease among the non-farm textilis. Ninety nine percent gained higher external orientation with better business stuff, and 98.o percent learned how to keep record of events.

Almost all (99.0\%) of those who were engaged in non-farm textile activities claimed that the innovation have exposed them to better technical methods of production with competitive marketing skills. Forty three percent had been opportune and exposed to the usage of certain sophisticated and modern equipment that augment textilis creativities in the field of operations. Seventy three percent of those who were engaged in fabric design signified that, the project have added value to their creativities in terms of motif and design development through the usage of catalogues and computers aided design (CAD). Other textiles and fashion fields mostly fashion industry boundaries specialties such as cosmetology, hair dressing and barbing, beads and jewelries designs among others were also introduced. The innovations have attracted other business opportunities to the study areas as indicated by 96.0 percent of the respondents. All (100.0\%) the respondents identified increased in income and prestige boosting as an attracting factor for adopting the project. Rating of R.A of introduced textile innovation was as indicated in Table 2.

Table 2: Table showing indicators strength values for introduced textile innovations $(\mathbf{n = 3 , 2 0 0 . 0})$.

\begin{tabular}{|c|c|c|c|c|c|}
\hline Indicators & Strength values & Means & $\begin{array}{l}\text { Standard } \\
\text { deviation }\end{array}$ & Frequency & Percentage \\
\hline \multirow[t]{3}{*}{ Relative Advantages. } & 21 and above [high] & & & 2,640 & 83.0 \\
\hline & Between 1.6 and 21.2[Average] & 11.35 & 9.8 & 560 & 18.0 \\
\hline & $1.6[$ low $]$ & & & o & 0.0 \\
\hline Total & & & & 3,200 & 100.o \\
\hline \multirow[t]{3}{*}{ Compatibility } & 38 and above (high) & & & 304 & 10.0 \\
\hline & Between 19.7 and 38.1 (average) & 28.9 & 9.2 & 2,886 & 91.0 \\
\hline & Below $19 \cdot 7($ low $)$ & & & o & 0.0 \\
\hline Total & & & & 3,200 & 100.o \\
\hline \multirow[t]{3}{*}{ Complexity } & 37.6 and above (high) & & & o & 0.0 \\
\hline & Between 19.1 and 37.6 (average) & 28.5 & 9.1 & 1,984 & 62.0 \\
\hline & Below 19.1(Low). & & & 1,216 & 38.0 \\
\hline Total & & & & 3,200 & 100.0 \\
\hline \multirow[t]{3}{*}{ Divisibility } & 8.4 and above (High) & & & 2,784 & 87.0 \\
\hline & Between 1.0 and 8.4 (Average) & $4 \cdot 7$ & $3 \cdot 7$ & 416 & 13.0 \\
\hline & Below 1.o(Low) & & & o & 0.0 \\
\hline Total & & & & 3,200 & 100.0 \\
\hline \multirow[t]{3}{*}{ Cost- benefit returns } & 7.o and above (High) & & & o & 0.0 \\
\hline & Between 2.6 and 8.6 (Average) & 4.8 & 2.2 & 126 & 4.0 \\
\hline & Below 2.6 (Low) & & & 3,072 & 96.0 \\
\hline Total & & & & 3,200 & 100.0 \\
\hline \multirow[t]{3}{*}{ Visibility } & Above 44.o (High) & & & 48 & 2.0 \\
\hline & Between 24.2 and 44.0 (Average) & 39.1 & $14 \cdot 9$ & 2,944 & 92.0 \\
\hline & Below $24.2($ Low $)$ & & & 208 & 7.0 \\
\hline Total & & & 3,200 & 100.o & \\
\hline
\end{tabular}

Source: Field survey, 2019.

\subsubsection{Complexity and compatibility}

Ability to meet requirements of any technology is a crucial determinant of its proficiency. If targeted audience could not meet requirements for an introduced innovation, sense of defeats and discouragement will set in (Oga, Kolawole, Thakadu, \& Masunga, 2015). Inputs maintenance is another factor that affects proficiency in production. For example inputs that are difficult to maintain or susceptible to constant damage will affect cost-profitability ratio. Seventy five percent of the 
respondents strongly agreed that skills requirements for the introduced textile packages were very easy to meet, and 25.0 percent were undecided. While 54.0 percent disagreed that the production techniques demands higher level of scholastic, 41.0 percent agreed and 5.0 percent strongly disagreed. About 33.0 percent disagreed that the training needs and knowledge requirements are very easy to acquire, 45.0 agreed and 22.0 strongly disagreed. Training needs of the innovation are averagely simple and clear but highly not specific as indicated by the respondents. All (100.0\%) the textilis indicated that, non- farm textile activities needs high level of creativities knowledge with constant inservice training for updating on textile and fashion trends. Production process of the introduced innovations was averagely stress free as indicated by 64.0 percent, 29.0 percent was scored low and, 7.o percent had a high score. Sixty three percent of the respondents strongly agreed that the project packages inputs were very easy to maintain, 27.0 percent agreed, and 9.0 percent disagreed. While 87.0 percent identified the introduced innovation as having its own peculiar risks, 96.o percent claimed that such risks were controllable.

Practically, all the respondents testified that it was highly possible to integrate introduced textile innovations and its requirements into the existing indigenous techniques. So, technique in TES could be built upon local knowledge. This supports Johnson (2014) who indicated that any innovation introduced must be compatible with the targeted group's experience and knowledge. Indepth study on technical skills entails in the packages of TES revealed 69.0 percent of the respondents as agreed that the technical process had been scaled down into indigenous knowledge except for fibre processing, and 30.0 percent strongly agreed. All (100.0\%) the respondents strongly agreed that most production mechanism involved were intermediates between local and modern methods. Hence, skill and techniques involved in the introduced innovations were related to the existing indigenous practices which connote compatibility with existing socio-cultural Bramas et al (2013) and economic activities. The innovation generates wastes that were water and land pollutants as indicated by the respondents. It was observed that, the waste management system practices on the introduced innovations were poor which ranges from unsystematic land-fill to open air-burn. Data in Table 2 presented project complexity and compatibility levels.

\subsubsection{Project divisibility and time efficient}

Divisibility is a crucial factor in the trial phase of an adoption. This might enable prospective adopter to demonstrate an innovation in a bit so as to confirm its potential rareness and values. Detailed analysis showed 96.o percent of the respondents to have identified packages of the introduced innovation as capable of been demonstrated in small bits and, that textile processes mechanism from production to consumption occurred in segments respectively. Ninety five percent identified each segment as potential specialties areas. Eighty one percent specified that, production fixed equipment are moderately available in a bit and 19.0 percent said it's not available. But all (100.0\%) signified that consumable inputs at each segment are available in a small bit. Ninety two percent specified textile delivery packages as capable of being operated along with other related projects on the same site. Levels of project divisibility were as presented in Table 2. The findings established that innovations introduced to the study area were highly divisible, which indicates that packages of such innovation could be practised or established on a small scale with little capital to start.

In depth analysis revealed 96.o percent of the respondents to had admitted that the reinvigoration of textile innovation is at the right time, particularly when many households were jobless and the country is going through critical economic distress and currency devaluation. Although, all (100.0\%) respondents were aware of other introduced family economic empowerment and development (FEED) programme, especially for youths, but specified that the introduced textile project is an alternative to the government agriculture scheme for national economic development. All (100.0\%) the respondents indicated that, production processes of the introduced on-farm TES packages could not be postponed in between operation without high economic loss, but the nonfarm packages were moderately unaffected. Again, ninety nine percent of the respondents identified 
the introduced non-farm textile enterprise as not having seasonal termination of patronage and production so; there is continuity in the enterprise.

Actual length of time for the training needs was assessed. Forty two percent spent between 6-12 months in training, $1-2$ years $(33.0 \%), 2-3$ years $(19.0 \%)$, and those that spent less than 6 months was 7.0 percent. Eighty nine percent of the textilis were engaged in textile enterprise before the introduced project so; the training given by the introduced innovation was a form of in-service training to augment the existing economic activities knowledge. Meanwhile, it was observed that androgyny training approach was adopted by the extension agency for TES delivery, where learner "will" retain control not only of his psychological commitment but of his actual application and maintaining the training. About 63.0 percent of the textilis spent less than 3 months on in-service training, 21.o percent spent 4 - 6 months and 16.o percent spent more than 6 months. It was observed that the introduced innovation have short time - output ratio, and short production lifecycle. They further clarified that non-farm textile processed lesser production lifecycle than on-farm textile. The project was scored to be highly time efficient by 78.0 percent and average by 22.0 percent of the respondents. From the finding it could be said that the introduced textile innovation was time efficient,

\subsection{Project visibility}

Project visibility was examined in order to ascertain the type introduced; accessibility; attractiveness; land and market basics among others. The project levels of visibility were as shown in Table 2 .

\subsubsection{Types of introduced textile innovations and attractiveness}

Most prominent on-farm textile packages introduced were fiber production (97.0\%), leather/skin production (71.0\%), and rubber/latex production (68.0\%). Introduced non-farm textile packages were clothing construction (99.0\%), fabric design (96.0\%), fabrication/fabric construction (78.0\%), leather works $(75.0 \%)$, textile care $(72.0 \%)$, and fiber processing/yarn production $(69.0 \%)$, respectively. Other sub - textile innovations introduced include fashion boundary specialties (98.o\%) (i.e. jewelry designer, beauty/hair and make-up artist among others), soft furnishing design (94.0\%), textile and fashion merchandising and branding (63.0\%), fashion stylist and consultant (61.0\%) among others. The aforementioned are textile extension delivery under Women - In- Agriculture unit of the extension agency in Nigeria. While 61.o percent of the respondents showed interest and participated in all the introduced innovations, 46.o percent adopted fiber production and processing, fabric designing $(61.0 \%)$, textile fabrication $(51.0 \%)$, leather work $(57.0 \%)$, clothing construction and design (64.0\%), beauty/hair and make-up artist (67.0\%), jewelry design (49.0\%), merchandising and branding (54.0\%), event producer/manager (52.0\%), fashion stylist (53.0\%) and, just 24.0 percent on textile care as indicated in Table 3. Low level of interest and participation in textile care and wastes management/recycling was in accordance with findings of Ewa (2016) who submitted that, most Nigerians are still very close to the nature which promotes cultural traditions and myths hence, negative attitude towards textile care and waste management/recycling entrepreneurship.

Assessments of the project outputs attractiveness showed that, little above average $(55.0 \%)$ have average score on innovations outputs attractiveness and appealing, 36.o percent had high, and 9.0 percent was low. Outputs attractiveness is a means of arousing interest and willingness during adoption process of an innovation. This might accountable for mass participation in the project. From the above findings, both on-farm and non-farm textile innovations were introduced and, people participated and adopted more than one textile innovations enterprise as sources of income. Participation is a sign of reception which could encourage adoption hence, economic empowerment. 
Table 3: Distribution of respondents according to introduced and adopted innovations

\begin{tabular}{lcccc}
\hline Textile innovations & $\begin{array}{c}\text { Introduced } \\
\text { Frequency }\end{array}$ & $\%$ & $\begin{array}{c}\text { Adopted } \\
\text { Frequency }\end{array}$ & $\%$ \\
\hline On-farm Textile innovations & & & & \\
Fibre production & 1,280 & 97.0 & 607 & 46.0 \\
Leather/skin production & 937 & 71.0 & 684 & 52.0 \\
Rubber/latex production & 897 & 68.0 & 515 & 39.0 \\
Horticulture/floweriest & 845 & 64.0 & 436 & 33.0 \\
Non-farm textile innovations & & & & \\
Clothing construction & 1,306 & 99.0 & 911 & 69.0 \\
Fabric design & 1,267 & 96.0 & 805 & 61.0 \\
Fabrication & 1,030 & 78.0 & 687 & 53.0 \\
Leather work/design & 999 & 75.0 & 754 & 57.0 \\
Textile care & 950 & 72.0 & 317 & 24.0 \\
Waste management & 1,175 & 89.0 & 141 & 11.0 \\
Cosmetology & 1,294 & 98.0 & 869 & 67.0 \\
Jewelry design & 937 & 71.0 & 647 & 49.0 \\
Soft furnishing items making & 1,240 & 94.0 & 702 & 54.0 \\
Merchandising & 832 & 63.0 & 568 & 43.0 \\
Fashion stylist and consultant & 805 & 61.0 & 670 & 53.0 \\
Event planners & 1,047 & 79.0 & 686 & 52.0 \\
Stage and home maker/decorator & 977 & 74.0 & 660 & 50.0 \\
\hline
\end{tabular}

Source: Field of survey, 2019.

\subsubsection{Project accessibility}

Training needs on the introduced project (on and non-farm) were averagely available. While the onfarm textilis specified that, primary on-farm textile training needs are available and easily accessible in the study area, non-farm training needs were not available and accessible. All the respondents that were engaged in fibre processing, fabric fabrication, fabric design and leather work agreed that equipment which could make their products compete with, or be of the same qualities with those from the developed countries were highly not available, nor affordable in the study area. Those who were engaged in textile care and jewelry artist hinted that equipment were moderately available, but also not affordable.

One hundred percent of those who adopted non - farm textiles innovations explained that they used local equipment with little modification, and that most inputs of the non-farm packages introduced were "consumable" (such as fabrics, yarn, additives and others) hence inputs were available. Eighty nine percent agreed that spare parts for modified indigenous equipment were accessible in the study area, but 11.0 percent disagreed. Ninety six percent agreed that spare parts were affordable, but 4.0 percent strongly disagreed. Those who disagreed were engaged in textile care and leather works. Sixty one percent of the respondents agreed that local technicians were available in the study environment for the modified indigenous equipment, 15.0 percent strongly agreed, and 24.0 percent disagreed.

One hundred percent of the on - farm textilis indicated that, major farm equipment were not available. The major equipment identified by 98.0 percent of this group were tractors, planting; spraying; harvesting and ginning machines. The study observed that, the available standard ginning machines were imported into the nation by federal government in the 7os, and was planted in Guzo, a community in the northern part of Nigeria. At the period of installation there were 28 ginning machines, as of the time this study was been carried out only three were functioning. Apart from the fact that, these machines were neither available locally nor affordable, the location of the few that were available was too far to be reached by most textilis.This could account for reasons why on-farm 
textilis sold their produce unprocessed, and invariably this could attract low price. Availability of equipment and spare parts enhance work force effectiveness and remove drudgery of manual labour. Sixty one percent disagreed that consumable inputs such as fertilizer and improved seeds were easily available, 15.0 percent strongly disagreed, and 23.0 percent agreed. Seventy percent explained that consumable inputs were averagely accessible at the time needed from the local market in the metropolis, but not through extension agency. This study confirmed availability of consumable inputs. Just few $(63.0 \%)$ agreed that outputs from the introduced innovations were predictable and, 37.o percent disagreed.

\subsubsection{Source of information and inputs}

Sources of information on textile innovations delivery that were accessible to the respondents include radio (98.0\%), neighbors and friends $(94.0 \%)$ respectively. This was followed by group discussion $(22.0 \%)$, extension agents $(13.0 \%)$, meeting (11.0\%), and Contact Farmers (10.0\%). It shows that, the most common source of information to the textilis were personal like radio and local information channels Mohammed and Uddin ( 2018). About 84.o percent of the on - farm textilis often accessed inputs from markets within and outside the community, 7.0 percent often from old storage, and 19.0 percent seldomly from extension agents. The major source of inputs accessible to the non-farm textilis was general market in the metropolis. It could be deduced that inputs for the introduced projects were available and accessible mostly from local sources. Inputs from this source are not liable and might affect outputs. Projects with challenging information and without major access to basic inputs will kill interest and willingness.

Contact between change agents and textilis was also examined to determine accessibility of textile innovation delivery. About 98.0 percent claimed to have contacted extension agents mostly through mass media, while 53.0 percent had more than 24 but less than 36 contacts, 47.0 percent had less than 24 contacts in the past 3 years. This indicates that there were contacts between agents, and the respondents although not personal.

\subsubsection{Land and market basics}

In-depth examination into the project land and market basics indicated that on-farm textilis (100.0\%) demands the use of a large size of land hold for the introduced innovation, while 96.o percent of the non-farm textilis specified small size. Land accessibility is a crucial factor in production. This could be part of the reasons why majority of those that were engaged in on-farm textile innovations were male, because male have easy access to land than female in Nigeria cultural context (Okunade \& Oladosun, 2011).

The on-farm textilis explained that market price for produces were fixed by the federal marketing board across the nation and that, there were product - coordinators (middle men between farmers and marketing board) whose job is to purchase proceeds directly from the textilis and re-sell to the board. This implied that there was a constant market. Ninety nine percent of the non -farm textilis also identified an average accessible market for outputs round the year, and further clarified that products qualities advertises and attracts buyers. This group also indicated that although, there were product- coordinators but they are free to sell their products to other buyers at wish. It could then be said that, there were constant markets for textile innovation outputs. All the above findings implied accessibility of the project.

3.3 Socio-economic costumes of textile innovations: This was examined under the following selected variables

\subsubsection{Income size}

The mean income per annum of the respondents from textile enterprise was N326, 596.00 $\pm 26,401$. 
While 61.o percent kept records on textile economic activities, 39.o percent did not. The validity of income could therefore be ascertained, because most respondents had authentic records of business transactions. Judging by Nigerian federal government minimum wage of $\mathrm{N}_{1} 8$, ooo.oo per month (N6oo.oo/day), it could be said that most textilis lived above the poverty line. It then implied that the introduced innovations augment income level. This is a vital determining factor of proficiency for economic empowerment and development.

\subsubsection{Cost to benefits return of the innovations}

Thorough examination revealed majority (92.0\%) of the respondents as signified that the project required less capital to start, relative to profit. While 92.o percent identified less energy expenditure, 93.o percent said, it has short time-return benefits. Short time - return benefit enhances evaluation in decision- making process at the stage of adoption. No entrepreneur wishes to knot his principal longer than necessary hence, this feature of short-time return benefit might espouse economic efficiency of high output to input gross margin. Most (98.0\%) of the respondents identified the project packages as necessitate higher numbers of labourers. In any production, the larger the size of labour, the higher the outputs if well managed. In the early days, accessibility to free labours was the main reason for acquiring several wives and children in Africa, but this study discovered that, respondents gained access to labourers by hiring hence, job - creation for empowerment.

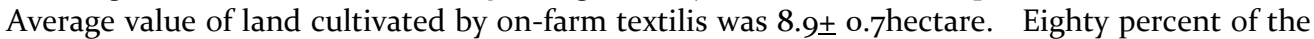
non-farm textilis operates on less than half a plot and 20.0 percent operates on more than half, but less than one plot of landhold. This showed that apart from on-farm textile innovations, other forms of the introduced projects required small landhold size hence, the non-farm packages of the project was land efficient. Levels of project cost- benefit returns are as showed in Table 2. It could be deduced that cost- benefit returns ratio of textile delivery of extension progamme was low, which means higher net income over low gross inputs.

\subsubsection{Prestige boost-ability}

In-depth analysis of the espousal of the introduced innovations identified 83.0 percent of the textilis as having high prestige and dignity scored and 17.0 percent scored average. These two indexes provoke inner motivation that enhances individual psychosocial growth and sense of belongings' in any society. This was adjudged by the observed improvement in respondent's standard of living with used of introduced innovations. All (100.0\%) the respondents specified that, their participation has not in any form defiled the society's notion of modesty, 96.o percent signified that the adoption had positive impact on their personality and lifestyle. Most (93.0\%) of the respondents contended that they have been able to purchase more fixed assets. One hundred percent highlighted that their association with the project has support their access to good food, housing, clothing and health care which are core essential human needs. About 53.0 percent owned a building, motorcycles (49.0\%), car (35.0\%), and 98.o percent could accessing good education for their children and wards. Fifty two percent of the textilis possessed an average ability, high (37.0\%) and low (11.0\%) to donate and contributes in materials and cash towards their family and community development due to the adoption. However, 99.0 percent stated categorically that, the project did not emphasize gender differences. This implied that the innovations gives equal opportunities to all sex, which invariably supports proficiency of the introduced project for sustainable economic empowerment and development of both sex.

Benefits attracted to the study area by introduced project were thoroughly reviewed, and 94.0 percent of the textilis believed that the project had attracted more customers to the areas from other LGAs within the State, outside the State $(81.0 \%)$, and outside the country $(52.0 \%)$. Ninety nine percent of the respondents indicated that the project had attracted and creates several other job opportunities in the study community. These job includes; trading (97.0\%), hospitality center 
(91.0\%), shopping complex (57.0\%), pharmaceuticals store (42.0\%), supermarket/stores (33.0\%), transport services (91.0\%), ICT service centre (96.0\%), mechanic/vulcanizes $(67.0 \%)$ respectively among others. These finding established the fact that respondents were making contact with people of different ethnics and racial belongings tribes and races consistently and so, heightened socialization which might advance respondents psychosocial, knowledge and, economic awareness.

\subsection{Proficiency}

The mean proficiency score was 17.1 with standard deviation of 2.9. The level of proficiency was determined with mean scores of \pm one standard deviation. Data in Table 4 shows that 66.o percent of the respondents had proficiency scores between 14.2 and 17.1 (average level), while 21.0 percent had proficiency scores between o and $\mathbf{1 4 . 2}$ (low level). This implies that majority of the respondents had average level of proficiency scores for textile innovations. It could therefore, be inferred that textile innovations delivery of extension service programme in Nigeria is averagely proficiency for rural economic empowerment and development.

Table 4: Distribution of respondents according to proficiency level of textile innovations $(\mathrm{N}=3$,220.o. $)$

\begin{tabular}{lcc}
\hline Effectiveness level & Frequency & Percentage \\
\hline o- 14.2 (Low level) & 672.0 & 21.0 \\
$14.2-17.1$ (Average level) & $2,112.0$ & 66.0 \\
Above 17.1 (High level) & 416 & 13.0 \\
\hline Total & $\mathbf{3 , 2 0 0}$ & $\mathbf{1 0 0 . 0}$ \\
\hline
\end{tabular}

Mean $=17.1$.

Standard Deviation $=\mathbf{2} .9$

Source: Field survey 2019

\subsection{Results of Factor analysis:}

Data were subjected to principal component analysis. This was with a view of isolating variables which were actually contributive to the principal factors influencing proficiency of textile innovation delivery for economic empowerment and development. Data in Table 4 presents three major factors that were isolated with latent roots as associate with proficiency of textile innovations. These are; socio-technical of the projects $(\lambda=5.8487)$, accessibility of textile innovations $(\lambda=4.2945)$ and, income factor $(\lambda=3.6393)$. The percentage variation as attributed to each of the factor components was given in order of their contribution as follows, socio-technical (25.09\%), and accessibility (23.74\%) and, income of textile innovations (20.25\%).

Table 5: Factor analysis showing variables contributing to socio - technical, accessibility and income factors of textile innovations towards proficiency

\begin{tabular}{lccc}
\hline Variables(socio-technical factor $\boldsymbol{~}$ ) & $\mathbf{L}$ & $\mathbf{L}^{2}$ & $\lambda$ \\
-relative advantage & $0.9631^{*}$ & 0.9276 & \\
-visibility & $0.8990^{*}$ & 0.8082 & \\
-cost-benefit return & $-0.8575^{*}$ & 0.7353 & \\
-time efficient & $0.8522^{*}$ & 0.7262 & $\Sigma \mathbf{5 . 8 4 8 7}$ \\
-training need & $0.8209^{*}$ & 0.6739 & \\
-prestige boosting & $0.8205^{*}$ & 0.6732 & \\
-complexity & $-0.8111^{*}$ & 0.6579 & \\
-attractiveness & $0.8040^{*}$ & 0.6464 & \\
Variables(incom factor ii) & $\mathbf{L}$ & $\mathbf{L}^{2}$ & $\lambda$ \\
-patronage & $0.8570^{*}$ & 0.7344 & \\
-cost - benefit returns & $0.8291^{*}$ & 0.6874 & $\Sigma_{33.6393}$ \\
\hline
\end{tabular}




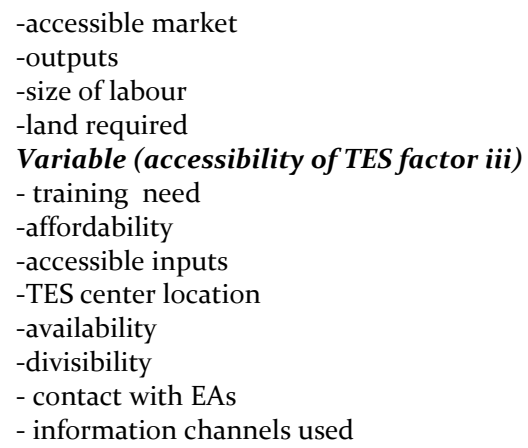

* = Highly contributive to the factor at o.o1 level.

$\mathrm{L}=$ loading for factor.

$\dot{i}=$ Latent root of the factor $\left(\sum \mathrm{L}^{2}\right)$

Source: Field survey, 2019

This finding showed that socio-technical values of the project, income and accessibility factors of textile innovations were mostly associated with proficiency. While 69.1 percent of the variation in proficiency of textile innovations score was explained by the three crucial factors isolated in the study, 30.9 percent variation was explained by all other unknown factors. Percentage of the unknown factors may have been due to contributions of several other factors whose influences were not isolated in this study. Therefore, to be proficiency for economic empowerment and development, textile innovation packages must be technically sounds, and apart from raising awareness through accessibility, it must be good and reliable source of income to boost economic status of the beneficiaries.

\section{Conclusions and Recommendations}

From the finding of this study it could be concluded that three crucial variables were extracted as responsible for the proficiency of textile innovations delivery. The factors were; socio-technical, accessibility of TES, and income of textile innovations. It was recommended that, the textilis (beneficiaries) must be able to access marketing board directly for sale of produce without middle men (products-coordinators). Apart from personal source of information, other cosmopolitan's sources of information should be put to use by the extension agents. Inputs must be made available at an affordable price in the various extension centers. Agents should be encouraged to improve rate of visits made to beneficiaries and, time for such visitation must be convenient and acceptable by the audience.

\section{References}

Adeniji, O.B. (2011). Adoption of improved technologies for cotton production in Kastsina state, Nigeria, Unpublished Ph.D. Thesis. Ahmadu Bello University, Zaria, pp. 197.

Adeolu, O. O. (2016). "Factors affecting effectiveness of women participation in politics in Nigeria", Unpublished Ph.D Thesis University of Ibadan, Ibadan, Nigeria, $p p .74$.

Adewumi, I. I. \& Okunade, E. O. (2016). Influence of Socio- economic Characteristics in Participation in Fadama ll Project in Ekiti L. G. A. of Kwara State, Nigeria. Journal of Rural Sociology, 16 (1), pp. 57.

Ajila, K. O.\& Farinde, A. J. (2012). Knowledge and Skill Practices in Systemic Programming for Textile Extension Services of Agricultural Development. Journal of Agricultural and Rural Development.10, pp. 97-112.

Ajila, K.O. and Farinde, A.J. (2015). "Systemic aAppraisal of home economics extension services delivery in SouthSouth states of Nigeria", Journal of Agriculture and Rural Development, Vol.15, pp.32-47. 
Alam, M.K., Aboki, E., Gidado, E.H, Buba, D.D. (2013). “Economic Analysis of Cotton Production in Selected Local government Area of Taraba State, Nigeria”, Journal of Agricultural Sciences, 4(1), pp. 27-32.

Alao, J. A., Agboola, A. F., \& Olaniyan, O. F. (1997). Determinants of Appropriate Technologies for Sustainable and Development in Nigeria. Journal of Nigeria Rural Sociology Association. 9 (2), pp. 19.

Ayinde, J. O. (2012). Assessment of Community Based youth Organizations Involvement in Rural Development Activities in Osun State, Nigeria. Unpublished Ph.D. Thesis. Obafemi Awolowo University, Ile - Ife. Nigeria, pp 76.

Branas-Garza, P, Anthonio M. and Shoshana N. (2013). "Effects of Religiosity on Social Behaviour: Experimental Evidence from a Representative Sample of Spaiaards”, IZA Discussion Papers, No.7683, Institute for the Study of Labor (IZA), Bonn, Germany. http://hdl.handle.net/10419/90o66.

Ewa, T. M. (2016). Factors Affecting Laundering Enterprise among Youths in Southwestern States of Nigeria.Unpublished M.Sc. Thesis. Adekunle Ajasin University, Akungba, Ondo State, Nigeria, pp.37.

Iwuchukwu, j, C. and Igbokwe, F.M. (2012). Lesson from Agricultural Policies and Programmes in Nigeria. Journal of Law, Policy and Globalisation. 5, 11-16

Johnson, D. D. (2014). Youth Participation in Agricultural Development Programme in Northern States of Nigeria. Unpublished Ph.D. Thesis, Federal University of Technology, Markurdi, Benue State, Nigeria, pp. 45.

Kolawole, O.D. and, Torimiro, D.O. (2005). "Participatory Rural Entrepreneurship Development for Grassroots Transformation: A Factor Analysis”, Journal of Human Ecology, 18(3) pp.195.

Mohammed, Z. A. and Uddin M. R. (2018). "Use of Information and Communication Technologies by Farmers in Receiving Agricultural Information”, Research in Agriculture Livestock and Fisheries. Vol ,(1), pp.71.

NAERLS (2008). National Agricultural Extension Review and Planning Meeting. Report No oog, Zaria. NAERLS Press Nigeria, pp.57.

Ndagara, S.B. (2005). "Rural Development Administration. In Bello, K. (Ed.), Essential of Public Administration. Flash Book Publisher, Kano, pp.139.

NEEDS (2015). National Economic Empowerment and Development Strategies Report xiv. 166. National Planning Commission Periodical Vol.2, Nigeria, pp.93

Odewumi, I.I. and, Okunade, E.O. (2016). "Influence of Socio-economic Characteristics in Participation inFadama II project in Ekiti Local Government Area of Kwara State, Nigeria,” Journal of RuralSociology.Vol.16.No. 1, pp. 73-79.

Okunade, E.O. \& Oladosu, I.O., (2011). Gender Differential in UNDP Skill Acquisition Centre on Poverty Alleviation among Youths in Ogbomoso South Local Government Area, Oyo State. Journal of Rural Research and Information, 6 (2), pp. 39.

Oga, S.R.., Kolawole, O.D., Thakadu, O.T. \& Masunga, G. (2015). Small farmers' adoption behaviour: Uptake of elephant crop-raiding deterrent innovations in the Okavango Delta, Botswana. African Journal of Science, Technology, Innovation and Development, 7(6), 412.

Ogbimi, F.E. (2006). "Causes and Remedies for Poverty in Nigeria”, Society for Linking Education and Problems. Obafemi Awolowo University, Nigeria. 1: (5), pp.96.

Oluwatoyin, I.B. and Adesoji, S.A. (2011). "Empowering Women through Information and Communication Technologies: Emerging Challenges and Prospects in Rural Nigeria”, In Faborode and Farinde (Eds.), African Women and Rural Environment. Post-Harvest Technology Research Group, pp.35-45.

Onjeiwu, S. (1997). "The Mordern Textile Industry in Nigeria: History, Structural Change, and RecenDevelopment”, Textile History). Vol. 28. No. 2, pp.234-249.

Opler, M.E. (2015). "Problems Concerning Official and Popular Participation in Development Projects",Economic Development and Cultural Change.Vol.64. No.1. The University of Chicago press, pp.269-178. https://www.jstor.org/stable/1151626.

Oye, G.A. (2019). "Assessment of Technology Utilization among Rice Farmers in Southwestern Nigeria”,Unpublished Ph.D. Thesis, Obafemi Awolowo University, Ile- Ife, Nigeria, pp. 268. 